\title{
Immunological Synapses in Infectious Diseases
}

\author{
Rodrigo Siqueira-Batista ${ }^{1}$, Mauro Geller ${ }^{2}$ and Andréia Patrícia Gomes ${ }^{3}$ \\ ${ }^{1}$ Professor of Internal Medicine, Neuroscience and Immunology/Microbiology, Centro Universitário Serra dos Órgãos (UNIFESO); ${ }^{2}$ Professor of \\ Immunology and Microbiology, Centro Universitário Serra dos Órgãos (UNIFESO); Coordinator of Genodermatosis, Genetic Services, \\ Instituto Puericultura e Pediatria Martagão Gesteira (IPPMG), Federal University of Rio de Janeiro (UFRJ); ${ }^{3}$ Professor of Infectious Diseases, \\ Centro Universitário Serra dos Órgãos (UNIFESO); Teresópolis, RJ, Brazil
}

The first conceptualization that the immune system (IS) could possess a communication mechanism analogous to the chemically-mediated neuronal synapses was developed by Norcross in 1984 [1]. In 1988, the observation that the T lymphocytes are capable of releasing cytokines in a specific direction - or, from a specific membrane region - allowed he revisiting of the notion of a synapse. The synapse was subsequently defined based on the intimate contact between two cellular surfaces, promoted by the binding of proteins present in both membranes [2]. Finally, in 1995, experimental results related to the interaction between cells of the IS were presented, demonstrating that the cellular membrane surface proteins of the interacting cells are organized following a pattern resembling a target in the contact region between the cells [3]. This notion was accepted until the consolidation of the idea of an immunological synapse, characterized as the transitory union between cells of the IS for the purpose of recognition, enabled by the 'shifting' of surface proteins to the interaction site.

An immunological synapse has been demonstrated among different cell types, including lymphocytes, antigen-presenting cells and natural killer cells, among others. Its organization is based on the disposition of proteins in the cell membranes, which dislocate to the interaction surface. The movement of these proteins is fundamental for synapse formation, especially because their respective spatial situations are altered during cellular communication. At first, recognition proteins are disposed around adhesion molecules (intracellular adhesion molecule-1/lymphocyte function-associated antigen-1, ICAM-1/LFA-1), characterizing an immature synapse. This disposition is later inverted so that the recognition proteins are found in the synapse's central region, surrounded by the adhesion proteins - characterizing a mature synapse (Figure 1) [4]. The movement of these proteins depends on the integrity of the cytoskeleton. However, other factors may also be involved.

A complete understanding of the interaction between the immune cells is one of the main requirements for the elucidation of the functional aspects of the IS, bringing new possibilities for a comprehension prioritizing a complexity-based ecological vision, in detriment of the classic bellicose concept of immunology. Moreover, there is a broad horizon of applicability of this knowledge in the different human illnesses. In fact, the role of the immunological synapse has been studied in the autoimmune diseases, acute myeloid leukemia, Burkitt's lymphoma and in organ transplant rejection, but, specially, in infections by HIV and HTLV-1 retroviruses [5,6]. Within the next few years, it is hoped that these investigations can bring significant contributions to the diagnosis and treatment of these disorders, increasing the curative possibilities of infectious disease medicine in the XXI century.

Figure 1. Organization of the mature immune synapse.

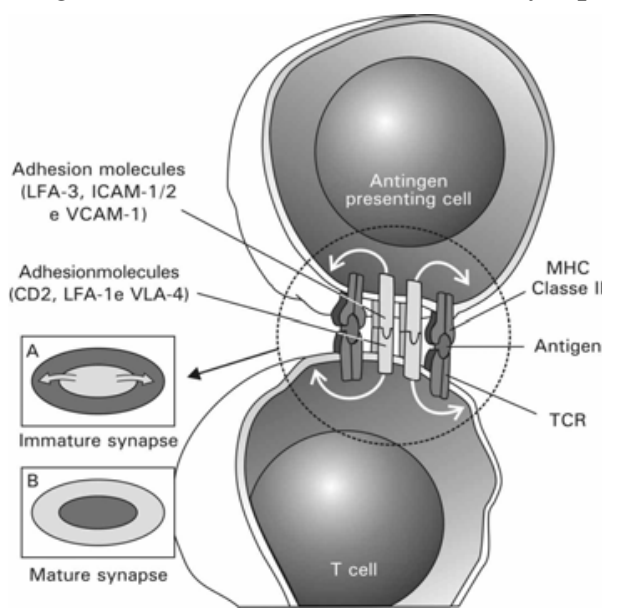

\section{References}

1. Norcross M.A. A synaptic basis for T-lymphocyte activation. Ann Immunol (Paris) 1984;135D(2):113-34.

2. Kupfer A., Kupfer H. Imaging immune cell interactions and functions: SMACs and the Immunological Synapse. Semin Immunol 2003;15(6):295-300.

3. Siqueira-Batista Geller M. Analogias entre o sistema imune e o sistema nervoso: o caso das sinapses imunológicas. SBI na Rede, São Paulo (http://www.sbi.org), v. 54, p. 2, 2006.

4. Dustin M.L. A dynamic view of the immunological synapse. Semin Immunol 2005;17(6):400-10.

5. Nejmeddine M., Barnard A.L., Tanaka Y., et al. Human Tlymphotropic virus, type 1 , tax protein triggers microtubule reorientation in the virological synapse. J Biol Chem 2005;280(33):29653-60.

6. Siqueira-Batista R., Geller M. Linfócitos e neurônios. Scientific American Brasil 2006;4(48):7.

\footnotetext{
Address for correspondence: Dr. Rodrigo Siqueira-Batista. Centro Universitário Serra dos Órgãos. Av. Alberto Torres, 111 - Alto Teresópolis (RJ) Brasil - Zip code: 25964-000. Phone: (+55 21) 2152-0000. E-mail: rsiqueirabatista@terra.com.br. Sources of funding: Programa de Iniciação Científica, Pesquisa e Extensão (PICPE), Centro Universitário Serra dos Órgãos (UNIFESO).
}

The Brazilian Journal of Infectious Diseases 2007;11(1):1. (c) 2007 by The Brazilian Journal of Infectious Diseases and Contexto Publishing. All rights reserved. 